\title{
DIALOGUL CULTURAL CU REPREZENTANȚII SOCIETĂṬII DE ADOPȚIE - CATALIZATOR AL DEZVOLTĂRII LITERATURII MIGRAŢIEI ÎN REPUBLICA MOLDOVA
}

\author{
EMILIA STAJILA \\ Universitatea de Stat din Moldova
}

\begin{abstract}
Rezumat. Independența Republicii Moldova a adus cu și vremurile grele pentru societatea care încă era cu gândul la fostul imperiu sovietic. Noile oportunități au fost găsite de moldoveni pe alte meleaguri, departe de casă. Migrația și Occidentul au favorizat în mare parte dezvoltarea literaturii contemporane din Republica Moldova. Experiența migrației și dialogul cultural cu societatea de adopție a scos talentul scriitoricesc al multor persoane din starea latentă. Pe lângă efectul paliativ, scrisul este și o exprimare a curajului, o depășire a unor prejudecăți plantate cu sârguință de regimul sovietic ecoul căruia se mai aude și acum în gândurile moldovenilor de pretutindeni. Scriitoarele din diasporă Lilia Bicec-Zanardelli, Tatiana Țîbuleac, Lilia Calancea, reușesc cu desăvârșire să demonstreze prin operele sale influența majoră a dialogului cultural asupra literaturii migrației.
\end{abstract}

Cuvinte-cheie: Migrație, brain drain, dialog cultural, incluziune socială, literatură.

Abstract. The independence of the Republic of Moldova brought with it hard times for the society that was still thinking about the Soviet empire. New opportunities were found by moldovian people in other lands, far from home. Migration and the West have largely favored the development of contemporary literature in the Republic of Moldova. The experience of migration and the cultural dialogue with the adoptive society brought out the writing talent of many people from the latent state. In addition to the palliative effect, the writing is also an expression of courage, an overcoming of prejudices diligently planted by the Soviet regime, the echo of which is still heard in the thoughts of moldovian people everywhere. The diaspora writers Lilia Bicec-Zanardelli, Tatiana Tîbuleac, Lilia Calancea, manage to perfectly demonstrate through her works the major influence of cultural dialogue on the literature of migration.

Keywords: Migration, brain drain, cultural dialogue, social inclusion, literature.

După o destrămare neașteptată a megasocietății sovietice, Republica Moldova s-a ciocnit cu nesfârșitele crize (economică, politică, socială, culturală). Aflându-se în situații dezastruase, tânăra țară a fost nevoită să se familiarizeze foarte bine cu noțiunea de migrație care nu este individuală, ci la 
nivel de grup. La începutul anilor ' 90 majoritatea oamenilor se orientau spre o emigrare în Rusia, imaginându-și că fosta ,soră mai mare” îi va ajuta să trecă peste situația economică foarte critică din țara de baștină. Așteptările au fost zădarnice. Existența și munca pe pământul rusesc erau antonimice în raport cu acel Eldorado proiectat în mințile încă sovietice ale moldovenilor. Au avut parte numai de irosire a timpului și a vieților. Situația în țara de baștină era aceeași, cu perspective deloc optimiste.

Spre sfârșitul anilor ' 90 moldovenii s-au redirecționat spre Occident. Până în anul 2007 migrația lor a avut cele mai mari proporții. Nu i-au oprit nici trecerile ilegale ale frontierelor și nici aflarea clandestină în țările europene. Backgraundul estic a jucat rolul său esențial. Deportările și iernile siberiene au călit până și genele moldovenilor și au creat o ,imunitate" rigidă ce privește greutățile, situațiile de risc și deznădejdea. După cum zicea istoricul francez Jacques Le Goff: „Pentru că ziua de astăzi se trage din cea de ieri, iar ziua de mâine este rodul trecutului..."

Fenomenul migrației aduce cu el multe și diferite subiecte. Acestea relevă consecințele migrației la nivel de societate, impactul experienței în țara de adopție asupra societății de origine, influența definitorie a fenomenului menţionat asupra conștinței de sine și a identităţii individului. Dezorientarea în privința ideii de apartenență și dezrădăcinarea se juxtapun cu integrarea socială a migrantului și dialogul cultural al acestuia cu societatea care 1-a adoptat. Având în vedere că în ultimii treizeci de ani, în Occident, se dezvoltă foarte rapid multiculturalismul, migrantul moldovean se ciocnește în țara de adopție cu o diversitate nemaipomenită de culturi. Încorsetarea personalității, rigiditatea normelor gândirii impuse de sovietismul demult mucigăit, însă deloc uitat, devin niște straie învechite ale mentalităţii care, treptat, sunt înlocuite de migrant cu normele democratice specifice Vestului.

Luat de valul procesului ,push-pull” al migrației, de avantajele oferite în țara de adopție, individul pășește tot mai sigur pentru a trece etapele de adaptare, integrare, incluziune socială și integrare civică. Ajungând să fie integrat, îi reușește nu doar să participe la dialogurile culturale, dar și să-și manifeste mai amplu talentul, cunoștințele pe care le-a dobândit în țara de origine. Majoritatea migranților fac parte din „brain drain”. Intelectualii emigrați în Occident au fost nevoiți treacă toate etapele menţionate mai sus, suportând umilință, sărăcie pentru a reuși să ofere familie un trai decent.

Nevoile parcurse, lumea nouă, dialogurile culturale cu reprezentanții societăţii de adopție au scos talentul de scriitor dintr-o stare latentă. Pe lângă experiențele noi ce trebuie împărtășite numaidecât, autori au simțit în creație un efect paliativ, catharhic. Diversitatea, democrația văzută în noua societate au scos curajul de sub reminescențele jegului sovietic și au reparat aripa condeiului. Migrația a oferit noi idei și scriitorilor rămași în Republica Moldova care au avut un teren vast de inspirații născute din experiența conaţionalilor 
plecați în lumea mare în căutarea unui trai mai bun. Au scris despre emigrare Constantin Cheianu (În container, 2007), Dumitru Crudu (Oameni ai nimănui, 2007), Val Butnaru (Avant de mourir, 2007), Claudia Partole (Viața unei nopți sau Totentanz, Jurnalul unei menajere, 2009; Straniera, 2020).

Poetul și dramaturgul Dumitru Crudu evidențiază: „În ultimul timp, migranţii înşişi s-au pus pe scris memorii în care îşi povestesc exilul european. Ei nu se îngrijesc neapărat de complexitatea scriiturii, de stil sau de unitatea naraţiunii, preferînd autenticitatea mărturiei. Dacă ar fi să comparăm ficţiunile literare ale scriitorilor cu textele memorialistice ale migranţilor ar trebui să constatăm că primele sunt cu mult mai realizate din punct de vedere estetic, dar cele din urmă sunt cu mult mai preţioase ca valoare a mărturiilor pe care le conţin, confirmînd încă o dată aserţiunea că faptul trăit este, de cele mai multe ori, cu mult mai imprevizibil şi mai năucitor decît cel închipuit de literaţi." (Crudu, 2009). Contactul direct și dialogul cultural cu societatea de adopție au un rol foarte important nu doar în acumularea experiențelor, dar și în șlefuirea mentalitătiii, a viziunii, în valorificarea diversitătii ca un dat și nicidecum ca o noutate incompatibilă cu propria individualitate. În opera sa Fabule moderne, scriitoarea Tatiana Țîbuleac ne atrage atenția asupra modului diferit în care noi, moldovenii, putem percepe sărăcia și la ce poli opuși este aceasta în Republica Moldova și în Franța (unde este stabilită scriitoarea):

„Întotdeauna m-am temut de sărăcie. De sărăcia cu miros de mucegai, umilitoare, cârpită și dureroasă. De sărăcia care te îmbătrânește înainte de timp și îți ciobește visele, unul câte unul, ca pe niște farfurii aruncate în certuri fierbinți. Altfel de sărăcii nu am știut că există.” Până și în concepția despre sărăcie atestăm backgroundul sovietic al moldovenilor. Totuși, dialogul cultural din Occident are un atu foarte important: învață o altă percepere a lucrurilor, a ideilor, a vieții. Autoarea continuă: „La Paris am învățat să fiu săracă. De la mamele cu mulți copii, majoritatea aici, de la studentele romantic și modeste, de la bătrânele în ciorapi de mătase pe orice frig, de la amantele subtile, pe care nu te poți supăra, de la casnicele care oricum ies în lume... De la femei. Am învățat că în viață poți avea doar un singur inel, dar scump. Că un parfum poate înlocui orice rochie. Că poți renunța la mâncare, nu și la un ruj. Că unghiile s-au născut colorate. Iar pielea curată. Că în casă poți avea doar o floare, dar vie. Că poți mânca doar o pâine, dar proaspătă. Că vinul trăiește în pahare, nu în sticle. Că o cafe poate ține trează până în dimineața unei noi vieți. Că o plimbare cu bicicleta te descoperă mai mult decât una cu o mașină de lux. Că o ciocolată trebuie să fie mai scumpă decât tot prânzul. Sau să îl înlocuiască. Că vacanțele sunt escapade, nu foi turistice. Că poți avea doar o noapte de dragoste, dar la limita nebuniei" (T,îbuleac, 2016, p. 31-32).

În Fabulele Tatianei Țîbuleac întâlnim poveștile de viață ale mai multor migranți din Republica Moldova, România, Portugalia, Georgia, ale 
francezilor în a căror societate s-a încadrat autoarea. Indiferent de naționalitate, fiecare om are în spate un drum parcurs, o poveste a vieții. Aceste istorii scrise cu atâta iscusință de Tatiana Țîbuleac ne inspiră să vedem latura pozitivă a traiului departe de casă, să înțelegem că fiecare om întâlnit în calea noastră nu e o întâmplare și diversitatea trebuie să scoată binele din noi, deoarece toți suntem, în primul rând, oameni cu toate că ne-am născut în țări diferite și nu vorbim aceeași limbă: „Îmi place diversitatea. Ea te pune la loc și, dacă ești prost, te învață minte". (Țîbuleac, 2016, p. 31-32).

Importanța dialogului cultural, perceperea sănătoasă a diversității și aspectul pozitiv al acestora sunt atestate și în scrierea Liliei Bicec-Zanardelli Testamentul necitit. Pe prima pagină autoarea reliefiază atmosfera de basm pe care o văzuse odată ajunsă în Italia și diferența totală între țara de baștină și societatea de adopție: „Ce am lăsat acasă? Desființarea fabricilor și uzinelor prin așa zisa privatizare, salariile date uitării, școli neîncălzite și sărăcie totală. În Italia am găsit o altă lume. N-am fost pregătită, dar am plecat..." (BicecZanardelli, 2018, p. 7). Un exemplu relevant de dialog cultural constructiv care ne demonstrează o mentalitate occidentală capabilă de a accepta cu respect diversitatea, multiculturalitatea este fragmentul în care Lilia Bicec-Zanardelli povestește cum a aflat semnificația cuvântului ,,presepio” (dioramă ce are ca subiect Nașterea Domnului). Gianluca, italianul în casa căruia lucra în calitate de dădacă, și-a dat seama că ea nu înțelesese explicația primită în limba italiană și a condus-o în curtea unei biserici să vadă personal ce înseamnă „presepio”, dăruind-ui și o carte despre tradițiile lor de Crăciun.

În opera sa, autoarea ne mărturisește nu numai despre dorul sfâșietor pentru copiii săi, despre umilința prin care a trecut emigrând în Italia, ci și despre diferite persoane, reprezentanți ai numeroaselor națiuni. Unii au umilit-o, alții au ajutat-o, fiindu-i alături atât în momentele tragice ale vieții, cât și în clipele frumoase. O idee semnificativă este că oamenii buni mai există și ei pot fi găsiți chiar la capătul pământului unde consideri că nu mai poți avea nicio speranță.

„De câteva ori am întâlnit grupuri de moldovence, doi ucraineni, la terasa unui bar stăteau câțiva marocani la o cafea. Peste tot numai străini. E plină Italia de noi. Duminica, în timp ce merg cu autobuzul, aud fel de fel de limbi, de parcă ar fi turnul Babel. Privesc uneori în jur, întrebându-mă: «Unde-s italienii?...»P Pe moldovence le recunosc după cerceii asemănători, producție rusească sau moldovenească, ucrainencele sunt blonde și vopsite un pic exagerat, romii nu pot fi confundați, ei sunt devotați portului și graiului. Românii sunt îmbrăcați după ultimă modă. Pe egipteni, indieni, africani îi cam confund între ei, dar sunt tot străini...” (Bicec-Zanardelli, 2018, p. 106).

Lilia Bicec-Zanardelli ne mărturisește cum simțea nevoia de a cunoaște cât mai bine limba italiană, de a afla despre cultura și tradițiile țării în care se află. Astfel, parcurgând etapele de adaptare, integrare socială, ajunge la 
incluziunea civică. Migranții, cei care au plecat din patria care i-a abandonat, au luat calea înstrăinării și a mirajului. „Majoritatea celor care au izbutit să treacă hotarul Moldovei nu au mai dorit să se întoarcă. Deși în disperare și înjosire, au continuat să rămână acolo unde o altă țară le-a dat un loc de muncă și speranța într-un viitor mai bun..." Greutățile trecute, nopțile nedormite, lucrul peste program, toate se uită atunci individul imigrat observă că societatea de adopție oricum îl primește, mai ales dacă vede un interes pentru cultura, tradițiile și viața din acea țară.

În Bocete de nuntă, Lilia Calancea (stabilită de mulți ani în Belgia) ne istorisește despre viața a mai multor migranți, inclusiv și despre experiența ei în calitate de emigrantă care poartă dorul pentru țara de baștină, pentru tradițiile și oamenii pe care nu-i va uita niciodată. Printre povestiri, scriitoarea include și un răvaș primit de la o veche cunoștință de a sa care plecase în SUA să-și dădăcească nepoții. Experiența traiului de acolo îi schimbase totalmente viața, ba mai mult, o apropiase de soțul său cu care era căsătorită de treizeci de ani și relația demult se răcise. Visul cuplului de a avea o viață mai bună era împlinit. Grijile și necazurile rămăseseră în Republica Moldova. Noua societate le-a oferit armonia pe care nici și-au putut-o imagina: „Trăim de parcă ne-ar fi trezit cineva dintr-un somn adânc și am descoperit ambii, cu stupoare, că viața noastră reală e cea din Philadelphia, iar tot ce a fost până la ea, în Moldova, a fost un coșmar lung de 30 de ani." (Calancea, 2019, p. 74). În ciuda maladiei depistate, această femeie își trăiește zilele așa cum și-a dorit, scriindu-i autoarei despre visul împlinit și clipele frumoase trăite abia la cincizeci și cinci de ani.

Fiecare emigrant, pe lângă amintiri, regrete, speranțe și visuri împlinite, mai simte și o stare confuză a sufletului, deoarece jumătate din inimă mai continuă să bată pentru baștină și tot ce îl leagă de acele meleaguri. O parte din oamenii plecați în străinătate și-au rupt dorul din rădăcină. Stabilindu-se în țara de adopție împreună cu toată familia, ei au devenit reci față de statul ce i-a gonit ușor, fără să încerce să îi rețină măcar încă un pic. Fiind emigrant în Europa Occidentală sau în SUA, apare posibilitatea de integrare, de afirmare și prosperare, pe când în Republica Moldova aripile sunt tăiate și concluzia apare de la sine unde se pune accent mai mult pe persoană: în țara de adopție, sau în țara-mamă care demult a renunțat vehement la copiii săi. Persoanele stabilite în străinătate au reușit să formeze familii mixte, să se asimileze în marea diversitate a lumii, astfel obținând o experiență culturală uriașă. Mentalitatea specifică sovietismului a fost refulată, poate chiar ștearsă cu ajutorul de noile idei. Astfel, scrisul a revenit în albia sa. Literatura migrației se dezvoltă, oferind noi opere de valoare și nume pentru care opera scrisă nu e doar rezultatul fanteziei colosale, ci și a vieții trăite în zbucium al sufletului, în vulcanul emoțiilor contraste.

Dialogul cultural cu societatea de adopție este nu doar o sursă de inspirație sau un element al catharsisului, ci și o sursă de noi valori, 
o descoperire a curajului, a încrederii în propriile forțe. În țara de baștină, necazurile, sărăcia, frica de judecata celor din jur, capul plecat de secole, umilirea extremă au îngropat inspirații, muze, talente. Abia pe pământuri străine, după lacrimi amare, coborâri, urcușuri, mici și mari victorii, spiritele creative ale moldovenilor plecați au renăscut, s-au regăsit în preocupările scriitoricești, în dialoguri purtate nu doar cu oameni, dar și cu propriile condeie însetate după noi rânduri.

\section{Referințe bibliografice:}

1. BICEC-ZANARDELI, Lilia. Testamentul necitit. Scrisorile unei mame plecate la muncă în Occident. Chișinău, ed. Cartier, 2018.

2. CALANCEA, Lilia. Bocete de nuntă. Chișinău, ed. Arc, 2019.

3. CRUDU, Dumitru. „Testamentul necitit” de Lilia Bicec. [online] Disponibil: https://moldova.europalibera.org/a/1892647.html [citat 29.08.2021]

4. ȚÎBULEAC, Tatiana. Fabule moderne. Brașov, ed. Libris Editorial, 2016. 